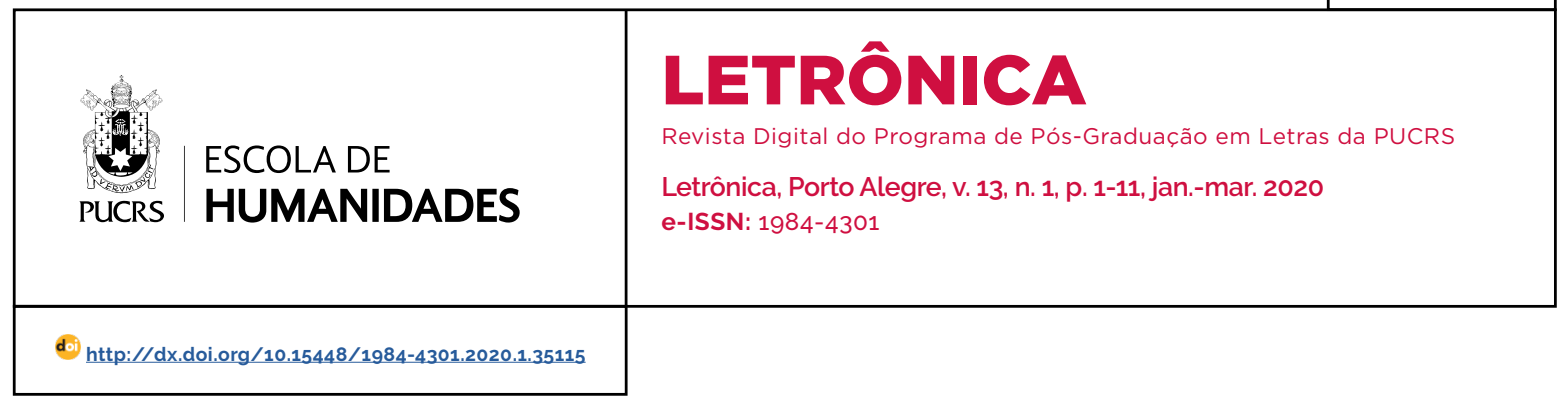

\title{
A trajetória de Rosa Maria Egipcíaca e o silenciamento cultural dos africanos no romance de Heloisa Maranhão
}

The trajectory of Rosa Maria Egpciaca and the cultural silencing of Africans in Heloisa Maranhão's novel

Francine Vargas dos Santos Damasceno ${ }^{1}$ orcid.org/0000-0002-6316-4024 franvargassd@gmail.com

Recebido em: 30 jul. 2019. Aprovado em: 16 dez. 2019. Publicado em: 7 abr. 2020.

\section{(c) (i)}

Artigo está licenciado sob forma de uma licença Creative Commons Atribuição 4.0 Internacional.
Resumo: Este estudo busca analisar o romance Rosa Maria Egipciaca da Vera Cruz (1997), de Heloísa Maranhão, apontando como essa narrativa revisa a realidade histórica do período colonial ao abordar aspectos ligados à condição feminina e ao apagamento cultural dos africanos escravizados. Para tanto, primeiramente, será analisada a relação entre a ficção e o documento histórico através da pesquisa de Luiz Mott (1993) sobre a africana Rosa Maria e do romance escrito por Heloisa Maranhão. Por conseguinte, serão averiguadas as características da metaficção historiográfica cunhadas por Linda Hutcheon (1991) presentes no romance, e também a forma como as questões históricas são articuladas na narrativa, levando em conta a trajetória da personagem Rosa Maria Egipcíaca.

Palavras-chave: Rosa Maria Egipcíaca. Metaficção historiográfica. Revisionismo. Escravidão.

Abstract: This study seeks to analyze the novel Rosa Maria Egipciaca da Vera Cruz (1997), by Heloisa Maranhão, showing how this narrative revises the historical reality of the colonial period and rescues aspects related to the feminine condition and the cultural erasure of the Africans enslaved. Therefore, it will be analyzed the relation between fiction and the historical document based on the research of Luiz Mott (1993) about african Rosa Maria and the novel written. Therefore, the characteristics of the historiographic metafiction coined by Linda Hutcheon (1991) will be investigated, as well as how the of these historical issues are articulated in the narrative, taking into account the trajectory of the character Rosa Maria Egipcíaca.

Keywords: Rosa Maria Egipciaca. Historiographic metafiction. Revisionism. Slavery.

\section{Introdução}

Em meados do século $X X$, o romance histórico passou por uma transformação em que sua forma foi reconfigurada visando à reinvenção do passado nas produções literárias. Os fatos marcantes como a ditadura, a discriminação racial e o holocausto impulsionaram esse resgate trazendo, através do campo literário, questões negadas pela historiografia oficial. Assim, a literatura pós-moderna desenvolveu uma reflexão crítica sem descartar o documento histórico, pois o escritor busca retratar fatos do passado sob uma ótica desestabilizadora. Para Linda Hutcheon (1991), a narrativa da pós-modernidade é classificada como metaficção historiográfica, pois "a ficção pós-moderna sugere que reescrever ou reapresentar o passado na ficção e na história é - em ambos os casos - revelá-los ao presente, impedi-lo de ser conclusivo e teleológico" (HUTCHEON, 1991, p. 147). 
Portanto, na metaficção há um resgate de fatos históricos através de uma concepção mais problematizadora que opta por uma versão dialógica dos acontecimentos. Essa recusa em aceitar respostas tradicionais ocorre por meio da construção de uma narrativa paródica em que o documento histórico não é simplesmente repetido, mas transformado através da intertextualidade, do pastiche e/ou da recontextualização. Desta forma, o texto é ressignificado e proporciona uma reflexão crítica acerca de versões sacralizadas sobre o passado. A partir de um diálogo individual e criativo com a história, a metaficção valoriza os personagens marginalizados pela historiografia reconhecendo assim a pluralidade existente no interior das sociedades. Ademais, ao ganhar espaço na narrativa, esses personagens mostram as contradições culturais apontando para uma inexistência de homogeneidade social.

Conforme Luiza Lobo (2002), os romances produzidos por mulheres no final do século $X X$ sofreram modificações, pois, ao contrário do que ocorria na década de 1970, as escritoras passaram a direcionar suas produções para o mundo exterior e não mais, prioritariamente, para o eu interior. Para Sandra Regina Goulart Almeida (2015), essas produções abordaram questões mais abrangentes em relação à figura feminina no contexto sociocultural e geopolítico. Porém, apesar dessas transformações, Regina Dalcastagnè (2008a) atenta para a ausência de representantes das classes populares não somente como produtores literários, mas também como personagens na literatura brasileira. Assim, segundo a pesquisadora, existe uma predominância de narrativas produzidas por uma "[...] classe média olhando para a classe média" (DALCASTAGNĖ, 2008a, p. 79). Isso deve-se ao fato de que os integrantes das margens não conseguem ocupar determinadas esferas sociais e acabam sendo sempre sub-representados.

Nesse sentido, a narrativa de Heloisa Maranhão, em Rosa Maria Egipciaca da Vera Cruz (1997), dialoga com essas questões, ao resgatar a voz de uma mulher silenciada pelo racismo e pelo sexismo, baseando-se nas memórias documentadas de uma sociedade escravista e patriarcal. Ademais, no romance, temos uma mulher dando voz a outra mulher, ambas marcadas pela opressão e apagamento social, porém em diferentes interseções. Existem pouquíssimos documentos sobre a trajetória de Heloisa Maranhão como escritora da mesma forma que existem somente rastros da existência de Rosa Maria. Mesmo assim, a ficcionista quebrou o silencio dos "marginalizados" ao (re) escrever a trajetória dessa Santa Africana da era colonial.

Desta forma, a partir de um rememorar da história, o romance revisa a formação da sociedade brasileira, tendo como base a pesquisa do historiador Luiz Mott (1993) acerca de Rosa Maria Egipciaca. Seguindo os passos dessa mulher emblemática, o texto ficcional resgata a temática da escravidão que percorre a narrativa e problematiza questões escondidas pela tradição, como por exemplo: a exploração feminina, a discriminação racial e a opressão exercida pela Igreja Católica. Por conseguinte, a escritora dá espaço para que as narrativas negadas sejam ouvidas, e fazendo uso da ironia, denuncia como os mecanismos de opressão geraram um apagamento dos elementos culturais africanos na concepção de uma identidade nacional brasileira.

Portanto, inicialmente, o presente artigo irá abordar o diálogo existente entre a literatura e a ficção através das produções de Luiz Mott (1993) e Heloisa Maranhão (1997), que trazem como personagem central das suas narrativas a africana escravizada Rosa Maria Egipciaca. Ademais, serão analisadas as características presentes na metaficção historiográfica que podem ser encontradas no romance em questão. Por conseguinte, será verificado como o texto ficcional revisa a história oficial, parodiando o documento histórico de Mott (1993) e problematizando questões ligadas ao sistema escravocrata presente nas raízes da história brasileira.

\section{Um diálogo com a história: o caso Rosa Maria Egipcíaca}

O romance contemporâneo Rosa Maria Egipciaca da Vera Cruz (1997), da escritora Heloisa Maranhão, resgata a pesquisa de Luiz 
Mott (1993) acerca da figura histórica Rosa Maria Egipciaca: uma mulher africana trazida para o Brasil na condição de escrava e que ganhou o reconhecimento de santa na sociedade colonial. Mott (1993) organizou sua pesquisa a partir dos documentos da Inquisição, localizados na Torre do Tombo, com os quais procurou reconstituir a trajetória da escrava negada pela historiografia oficial. A bibliografia produzida pelo historiador apresenta ao leitor a figura de uma mulher com um comportamento transgressor, pois, mesmo fazendo parte de uma sociedade escravocrata e patriarcal, Rosa conseguiu "negociar" com as estruturas de poder e ascender socialmente através da religião. Ela passou do status de prostituta (escrava de ganho) à santa, conquistando até membros do clero como devotos para o Recolhimento do Parto, fundado no ano de 1754, por ela e pelo padre popularmente conhecido como Xota-Diabos.

Conforme Mott (1993), a história de Rosa iniciou-se no Rio de Janeiro quando ela foi comprada por um senhor que a explorava sexualmente e depois a vendeu para a mãe do Frei de Santa Rita Durão. Na cidade de Minas Gerais, Rosa tornou-se prostituta e, após abandonar a prostituição, virou uma beata com visões e experiências místicas semelhantes às das santas legitimadas pelo catolicismo. Rosa afirmava ter aprendido a escrever através de uma visão celestial e, segundo Mott (1993), ela foi responsável pela autoria de um livro, com mais de duzentas páginas, intitulado Sagrada Teologia do Amor Divino das Almas Peregrinas. A obra registrava as visões e os pensamentos da ex-escravizada, porém, quando Rosa foi acusada de falsa santidade, ele foi destruído, pois poderia ser usado como uma prova.

Desta forma, dos seus escritos restaram apenas algumas páginas e algumas cartas que revelavam a aproximação da religião católica com a africana nos ritos religiosos comandados por ela. Madre Rosa, além de fundar o Recolhimento do Parto, introduziu aos fiéis uma nova modalidade de oração: o Rosário de Santana e a Devoção aos Santíssimos Corações. No Rosário de Santana, houve uma proposta de novos temas de reflexão espiritual, além da substituição da
Ave-Maria pela prece "Santana, nobreza do amor de Deus". É valido ressaltar que, ao fazer isso, Rosa propõe uma devoção à ancestralidade da Sagrada Família e acaba resgatando o culto aos ancestrais, um princípio religioso africano. Ademais, os praticantes da religião dos orixás associam o culto da Senhora Santana ao culto de Nanã Borocô, a mãe primitiva.

Segundo Mott (1993), Rosa também afirmava ter sido a ama de leite de Jesus Cristo e a detentora de uma visão apocalíptica. O processo analisado na Inquisição foi inconclusivo e não existe nenhum documento que aponte qual foi o destino Rosa. Porém, baseando-se na sua trajetória, o historiador apresenta duas alternativas para o desfecho da história da Santa Africana: a morte no cárcere da inquisição ou a possibilidade de que Jesus teria vindo buscar sua ama de leite (nessa última alternativa apresentando certa ironia em relação ao misticismo de Rosa).

A pesquisa desenvolvida por Mott (1993), permite conhecer uma figura emblemática da sociedade brasileira do periodo colonial. A partir dos rastros deixados por Rosa, o historiador dá veracidade a sua existência e apresenta a figura de uma mulher que, destinada à uma posição subalterna, conseguiu ocupar um espaço na sociedade, tornando-se o sujeito da enunciação por um determinado periodo. A ex-escravizada negociou com as estruturas de dominação, aprendeu a língua do colonizador e, através dela, questionou a cultura propondo uma ressignificação das verdades já sacralizadas. Porém, como já citado anteriormente, o historiador buscou os rastros, as ruinas da história de Rosa, pois essa mulher sofreu um processo de apagamento e silenciamento na historiografia oficial.

Assim, baseando-se na pesquisa de Mott (1993), a escritora Heloisa Maranhão também retoma o passado trazendo Rosa Maria Egipciaca para a posição central do seu romance. A personagem é o fio condutor para que se possa problematizar outras questões ligadas à sociedade do Brasil Colonial, especialmente ao que se refere à escravidão. A trajetória de Rosa no texto ficcional, revisa a história nacional dando voz a figuras silenciadas e abrindo espaço para as 
identidades que ameaçam uma tradição fundada no princípio da homogeneidade. Portanto, de acordo as pesquisas de Hutcheon (1991), a obra Rosa Maria Egipciaca pode ser considerada uma metaficção historiográfica, pois existe uma apropriação de personagens históricos marginalizados e uma problematização das verdades tidas como absolutas. No romance, a escritora apresenta uma nova versão para história de Rosa na qual os excêntricos ganham poder de fala e, consequentemente, revelam a pluralidade escondida pela tradição oficial.

Para Hutcheon (1991), a metaficção faz esse retorno ao passado de uma forma crítica e não nostálgica, pois a articulação entre a história e a literatura proporciona que o leitor questione a verdade transmitida como absoluta. Dessa forma, ela "estabelece a ordem totalizante, só para contestá-la com sua provisoriedade. sua intertextualidade e, muitas vezes, sua fragmentação radical" (HUTCHEON, 1991, 155). Assim, não há a rejeição da história, mas sim a subversão na qual a problematização substituiu a demolição. Portanto, as referências históricas são suspensas no momento em que a história é desvelada sob um outro ponto de vista e, sendo assim, a metaficção historiográfica apresenta uma referência duplicada: a suspensa e a desvelada. A autora ainda destaca que a pósmodernidade utiliza a paródia como um recuso narrativo e que ela se caracteriza como "[...] uma repetição com distância crítica que permite a indicação irônica da diferença no próprio âmago da semelhança" (HUTCHEON, 1991, p. 47). Portanto, conforme Hutcheon (1991) afirma, a paródia faz uma abordagem crítica da tradição permitindo o estabelecimento das diferenças e a recontextualização de fatos que passam a adquirir novos sentidos.

No romance Rosa Maria Egipciaca da Vera Cruz (1997), é possivel identificar essas questões através de alguns aspectos. O primeiro deles seriam as referências à bibliografia escrita por Mott (1993), ao mesmo tempo em que a autora constrói uma nova versão para vida da personagem. No texto ficcional, alguns fatos aparecem iguais à versão histórica, e isso acaba aproximando os dois textos e fazendo com que o romance apresente uma referência duplicada: a do historiador e a que está sendo revelada pela escritora. Outra questão relevante seria o fato de Hutcheon (1991) considerar a paródia, a estratégia narrativa daqueles que estão à margem do discurso dominante, pois eles teriam "[...] um acerto de contas e uma reação, de maneira crítica e criativa, em relação à cultura ainda predominantemente branca, heterossexual e masculina na qual se encontram" (HUTCHEON, 1991, p. 58). Assim, é possivel aproximar, mais uma vez, suas considerações sobre a metaficção historiográfica com a obra Rosa Maria Egipciaca da Vera Cruz (1997), pois o romance é escrito por uma mulher que dá voz a outra mulher escravizada no período colonial.

Consoante a isso, é importante discutir a questão da representatividade e, para tanto, a pesquisa de Dalcastagnè (2008b) aponta que o perfil dos escritores brasileiros com o maior número de livros publicados é composto por homens, brancos e pertencentes a uma classe social elevada. Dessa forma, evidencia-se que a mulher está à margem no cenário das publicações literárias e, quando se trata de uma mulher negra, ela encontra-se em uma posição ainda mais marginalizada, pois somente $2,7 \%$ das mulheres negras ocupam a posição de narradoras e 5,8\% são protagonistas. Assim, esses dados corroboram para enfatizar a importância do romance analisado, pois ele é de autoria feminina e apresenta uma mulher negra como personagem principal e que também age como uma coautora.

Conforme citado anteriormente, Heloisa Maranhão dá voz a uma personagem marginalizada pela historiografia oficial, fazendo com que o leitor tenha acesso a um outro ponto de vista acerca da formação da sociedade brasileira. Ademais, na pesquisa do historiador, a bibliografia é construida por um olhar masculino que utilizou documentos possivelmente mediados por um outro homem. Dessa forma, a voz de Rosa aparece apenas de uma forma fragmentada, através das ruínas da sua existência, como, por exemplo, nas cartas 
escritas por ela e, portanto, o texto acaba sendo construido a partir de uma seleção da cultura dominante. Por conseguinte, pela precariedade de documentos, Mott (1993) precisou preencher as lacunas com outros acontecimentos e outras histórias que se cruzaram com a de Rosa. Já o romance cria a possibilidade para que a própria Rosa conte sua história e, através do seu olhar, é possível revisar o passado. Durante a narrativa, os escravizados ganham o direito de fala e, consequentemente, trazem reflexões acerca do Brasil no periodo colonial, principalmente, no que se refere ao sistema escravocrata.

Assim, é possivel afirmar que a produção dos dois autores, cada um a seu modo, faz um revisionismo da historiografia oficial, ao abordar a vida de uma personalidade negada pelo discurso dominante. Para Walter Benjamin (1987) o resgate da história precisa ser feito no intuito de olhar os elementos do passado para recuperar a presença daqueles que não tiveram espaço na história e foram silenciados pelo processo de dominação. Segundo o filósofo, todos os acontecimentos são importantes, inclusive a história dos vencidos e os fatos tido como menores. Em vista disso, nasce a necessidade de questionar as verdades tidas como absolutas e uma historiografia que se baseia apenas em questões ligadas ao lado vencedor/ colonizador. Dessa forma, tanto o texto ficcional quanto o documento histórico procuraram contar os fatos que ficaram escondidos, trazendo para o centro da discussão uma mulher oprimida e marginalizada pela sociedade. Essas produções mudaram o foco dos estudos enfatizando o passado dos excluidos para que se possa refletir sobre o sistema escravocrata presente na sociedade brasileira e a forma como ele ainda condiciona certas ações que continuam a excluir/marginalizar os negros na sociedade contemporânea.

\section{A voz de Rosa Maria e a (re)construção da história brasileira na ficção de Heloisa Maranhão}

O romance Rosa Maria Egipcíaca da Vera Cruz (1997) tem como personagem central uma africana trazida para o Brasil na condição de escrava que ascendeu socialmente, ao herdar do seu senhor e amante uma mina de ouro. Antes de ser escravizada, Rosa Maria era a princesa de Benim e se chamava Xirico, porém, ao chegar no Brasil com 15 anos, ela foi comprada por Dom Diogo Velho Cavalcanti, com quem perdeu a virgindade e tornou-se sua "escrava favorita". No início da narrativa, a personagem apresenta-se de uma forma hibrida, pois continua ligada as suas raízes mesmo sendo forçada a aderir a cultura do colonizador. Rosa procura resgatar elementos da África para compreender o espaço brasileiro e mantém vivos os ensinamentos da sua avó, a rainha Derumo. Apesar de ter sido batizada com outro nome, entre os escravos ela é chamada de Xirico, e pratica a religião de matriz africana ao invés do catolicismo. Ademais, a personagem mantém a conexão com a sua guia espiritual, Xipoco-Xipocué, sendo detentora de visões e de um poder sobrenatural capaz de curar uma criança na fazenda de engenho.

Outro aspecto relevante é que Rosa aproxima - Brasil da África na tentativa de fazer parte do ambiente brasileiro. Ela vê na floresta, no contato com a natureza, um espaço aconchegante no qual pode relembrar suas origens. A personagem utiliza palavras africanas para se referir a certos elementos, demonstrando que, mesmo estando inserida em uma outra cultura, ela se esforça para não se distanciar da sua tradição: "Várias grutas as quais eu chamo de vários nomes. Majumbo que na África são tripas, dessas que servem para cozinhar, Timbila que é o nome de um instrumento musical no Benim [...]" (MARANHÃO, 1997, p. 26). Portanto, através da memória, a personagem dialoga com o seu passado, apresentando-se como um sujeito deslocado e dividido entre a nação de onde veio e a nação em que está.

Porém, a postura de Rosa muda quando D. Cavalcanti morre e deixa de herança para ela uma carta de alforria e uma mina de ouro na cidade de Vila Rica. Xirico torna-se livre e passa a ocupar uma posição de destaque na sociedade: a de proprietária de terras. Para tanto, ela muda-se para Vila Rica na companhia do padre Xota-Diabos e, nessa travessia, passa por uma preparação espiritual para ocupar 
o novo espaço. Rosa tem sonhos e visões que a aproximam do catolicismo e a advertem sobre os perigos de não aderir a cultura do colonizador. Em um desses sonhos, a personagem conversa com Santa Rosa de Lima e é questionada sobre a sua religiosidade e sobre a possibilidade ser portadora da Rosa de Ouro, um ornamento abençoado pelo Papa e entregue às pessoas leais à Santa Sé: "Você é cristã, princesa Xirico do Benim? O Papa poderia enviar-lhe a rosa para honrar suas virtudes" (MARANHÃO, 1997, p. 125).

Através desse diálogo, percebe-se que nessa nova fase de Rosa não há espaço para o hibridismo que a caracterizava até o momento. $O$ questionamento da santidade está relacionado à incompatibilidade de ser a princesa de Benim, praticante do candomblé, e cristã ao mesmo tempo. Após o sonho, a personagem deixa essa questão mais explícita, quando passa a preocupar-se em ser um boa cristã e chega a planejar construir uma igreja em Vila Rica. Ademais, durante a viagem, o padre exorcista faz orações em latim como se estivesse enxotando os maus espiritos e preparando-a para ocupar a posição de proprietária de terras.

Esses fatos demonstram que na sociedade colonial não havia espaço para o hibridismo cultural simbolizado por Rosa e, portanto, para fazer parte daquele meio era preciso aderir à cultura do colonizador. No início do romance, a personagem ainda está ligada ao universo africano, pois, a todo momento lembra da sua pátria, dos ensinamentos de seus antepassados e pratica sua religião. Porém, ao "ascender" socialmente, Rosa perde a ligação com suas raízes e se readapta para pertencer a esse novo espaço. Em Vila Rica, a ex-escravizada tem pela primeira vez um lar e adere completamente ao catolicismo seguindo um modelo social em que a Igreja influencia diretamente na construção da vida coletiva e individual. Desta forma, a religião pode ser analisada como um fator fundamental para transformação da personagem, pois ela caracterizava-se como uma ideologia à serviço do opressor.

O processo de construção do romance também exemplifica a transformação sofrida por Rosa. Antes de dar início à narrativa, a personagem aparece para Heloisa Maranhão como se fosse uma entidade, ordenando que sua história seja escrita. Nesse momento, as duas parecem passar por um ritual de candomblé no qual Rosa ocupa o corpo da escritora. Como se estivesse em transe, Heloisa Maranhão é guiada por ela e começa a escrever a história da princesa Xirico. Porém, no final da narrativa, a personagem não está mais ligada à tradição africana, mas sim ao universo católico, tentando se tornar uma boa cristã ao expulsar os pecadores da Igreja. Suas últimas palavras no livro são: "Não vejo ninguém. Pessoas, altares, bancos, a igreja? Estou só. Tudo branco. Será que eu também? Vou desaparecer? Invoco o Deus cristão" (MARANHÃO, 1997, p. 234). Portanto, o final de Rosa no romance demonstra o processo de desafricanização sofrido pela personagem. Ela não tem mais suas referências religiosas, pois invoca o Deus e termina a narrativa dentro de uma igreja seguindo o ensinamento do padre.

A partir dessas questões, o romance acaba denunciando a instituição religiosa como uma estratégia do colonizador para subjugar os outros povos. A fé cristã simboliza um mecanismo de opressão e discriminação no qual os africanos eram submetidos assim que chegavam em solo brasileiro. Através do batismo, eles perdiam o direito de usar o próprio nome, de praticar a sua religião e, por conseguinte, passavam a usar nomes portugueses tendo sua história apagada dos registros oficiais. Conforme Abdias Nascimento (2016), a água batismal era vista como uma forma de erradicar a raça, tornando o africano em um branco-europeu superior àquele que ainda não tinha sido batizado. Desta forma, uma das primeiras agressões sofridas por esses povos se dava pela imposição religiosa através do batismo dos escravizados e, consequentemente, da negação da sua cultura.

Segundo Frantz Fanon (2008), a civilização branca impôs ao negro um desvio existencial, pois a colonização gerou um apagamento cultural. Dessa forma, conforme o romance exemplifica, a valorização da tradição eurocêntrica ocasionou a 
construção da imagem dos países africanos como povos ausentes de civilização. Por conseguinte, o "embranquecimento cultural" da personagem Rosa demonstra o desvio existencial em que o africano assimila a cultura do colonizador para, de certo modo, ser aceito por aquele grupo. Conforme Fanon (2008), essas questões geraram um complexo de inferioridade, que foi introjetado na mente dos negros, fazendo-os buscar estratégias que os aproximassem dos costumes do colonizador para livrarem-se do estereótipo de selvagens:

Todo povo colonizado - isto é, todo povo no seio do qual nasceu um complexo de inferioridade devido ao sepultamento de sua originalidade cultural - toma posição diante da linguagem da nação civilizadora, isto é, da cultura metropolitana. Quanto mais assimilar os valores culturais da metrópole, mais o colonizado escapará da sua selva. Quanto mais ele rejeitar sua negridão, seu mato, mais branco será (FANON, 2008, p. 35).

Porém, segundo o autor, por mais que essa assimilação cultural desloque o individuo do seu grupo de origem, o racismo não permite que ele se equipare ao europeu, sendo tratado com igualdade. Mesmo assimilando a cultura do colonizador, no momento em que ele tentar transcender determinadas fronteiras os mecanismos opressores irão reafirmar seu lugar de inferioridade. Os estudos de Edward Said (2011) também corroboram com essa questão, pois ele afirma que o imperialismo vai além das práticas econômicas e das decisões políticas, pois não está ligado apenas a uma questão territorial. Para o autor, o campo cultural é um fator fundamental nas relações de poder, pois a cultura pode ser analisada como uma estrutura de autoridade e de participação do imperialismo, uma vez que ela tem o poder de legitimar e/ou de rebaixar aquilo que é diferente ou oposto da sua imagem.

Além de abordar a negação da cultura africana, a narrativa também denuncia a participação ativa da Igreja no comércio de escravos. Segundo Nascimento (2016), ela foi um dos instrumentos dominação utilizados pelo colonizador, pois "possuía escravos com fins lucrativos e perseguia e atacava as crenças religiosas africanas [...]"
(NASCIMENTO, 2016, p. 124). Em uma passagem do romance, o padre Xota-Diabos faz essa mesma denúncia para Rosa Maria ao afirmar que:

É desesperante, mas a Igreja recebe da Coroa Portuguesa cinco por cento de comissão sobre a venda de negros escravos. Indigno imposto. É assim que a Igreja permite que "se resgatem os negros" e os transformem em escravos para conseguir batizá-los mais facilmente e impor-lhes o cristianismo (MARANHÃO, 1997, p. 152).

Ademais, a narrativa também problematiza as condições de trabalho oferecidas aos escravizados, destacando a forma desumana como eles eram tratados e reafirmando o Brasil como um país fundado sob o signo da exploração. Para isso, a autora enfatiza a relevância da mão de obra escrava na formação econômica do país através de dois momentos históricos: o período dos engenhos de cana-de-acúçar e o processo de mineração. Conforme Abdias Nascimento (2016, p. 59) a força de trabalho escrava foi de extrema importância para história econômica do Brasil, pois:

Sem o escravo, a estrutura econômica do país
jamais teria existido l...] Ele plantou, alimentou
e colheu a riqueza material do país para des-
frute exclusivo da aristocracia branca. Tanto
nas plantações de cana-de-açúcar e café e
na mineração, quanto nas cidades, o africano
incorporava as mãos e os pés das classes diri-
gentes que não se auto-degradavam em ocu-
pações vis como aquelas de trabalho braçal.

Nesse contexto de exploração e de subjugação, ao chegar em Vila Rica, Rosa Maria promove mudanças no que diz respeito ao regime de trabalho dos seus mineradores. Em sua mina, os africanos começam a ser vistos como trabalhadores e passam a ter direito a boas condições de trabalho e a lucros referentes ao ouro extraído. Na medida em que ela vai pontuando quais mudanças pretende fazer, surge a denúncia da condição hedionda que os escravizados eram tratados:

Todos os escravos serão alforriados, e os que quiserem continuar assim o farão nas seguintes condições: o ouro que extraírem, metade é deles, e a outra metade é minha. Quero que eles passem então suavemente de escravos a cidadãos deste país. As condições de trabalho serão rigorosamente revistas. Quero renovação 
de ar nas galerias. Não aceito homens morrendo sufocados ou soterrados. Não aceito hérnias nem pneumonias. Fim dos castigos. Não há mais escravos fujões que apanhados sofrem perda do tendão-de-aquiles de um dos pés, e que é cortado. E também não se destrói nenhuma artéria do pé de um escravo.

Segundo Keila Grinberg (2018), os castigos eram uma estratégia dos senhores para, através do medo, controlarem seus escravos. A violência física seguia uma lógica específica em que "a punição deveria ser pública, exemplar, reafirmando o poder do soberano ou do senhor" (GRINBERG, 2018, p. 145). A narradora do romance também problematiza os castigos sofridos pelas mulheres que, além da exploração referente à força de trabalho, tinham seus corpos violados. Rosa vê sua sinhá como alguém bondoso por não "servir como doce especial os olhinhos dessas negras bonitas, arrancados na ponta de faca, boiando em calda doce, como se tem feitos em tantos engenhos do Nordeste [...]" (MARANHÃO, 1997, p. 52). Portanto, a ideia de bondade está atrelada a não praticar o castigo cruel quando, na verdade, deveria ser relacionada com o fato de não praticar nenhum tipo de violência física ou psicológica. No caso de sinhá, não existe bondade, pois ela compactua com a violação do corpo das mulheres escravizadas do seu engenho ao manter "[...] na mesa do Sinhô negrinhas bonitas que o Sinhô elogia" (MARANHÃO, 2018, p. 52). Ademais, Rosa é a escrava favorita de $D$. Cavalcanti e serve sexualmente seu senhor e mais dois amigos dele, referidos na narrativa como Amigo $n^{\circ} .1$ e Amigo $n^{\circ} .2$.

Conforme Maria Helena Pereira Toledo Machado (2018), durante a escravidão, homens e mulheres ocupavam lugares distintos no sistema escravocrata e, portanto, eram submetidos a diferentes formas de opressão. As mulheres eram constantemente violentadas sexualmente, pois eram vistas como pessoas com a sexualidade exagerada e isso justificaria a violação por parte dos proprietários de terra. Além disso, muitas vezes, o estupro nas sociedades escravistas era visto como "um encontro amoroso, ou quase, ocorrido sob os auspícios de uma escravidão intima e adocicada" (MACHADO, 2018, p. 338). Segundo bell hooks² (2014), durante o periodo da escravidão, a mulher negra não era protegida por nenhuma lei ou opinião pública que impedisse a exploração sexual feminina. Portanto, essas mulheres se tornaram um alvo fácil, pois "[...] foi o sexismo que determinou que o destino das mulheres negras seria mais duro, mais brutal do que os homens negros escravizados" (HOOKS, 2014, p. 32).

Outro aspecto relevante do romance é que, ao cruzar pelo caminho de seus compatriotas, a personagem cede a palavra a eles, resgatando oralidade africana através do compartilhamento da história. Assim, diante de um sistema escravocrata em que as pessoas eram tratadas como objetos e mercadorias, esses relatos humanizam os personagens mostrando que por de trás daquelas pessoas existia uma identidade. Nesse sentido, pode-se retomar os estudos de Homi K. Bhabha (1998; 2011) em relação à enunciação feita a partir de grupos historicamente marginalizados que, através das suas narrativas, fissuram o imaginário social construido por uma tradição homogênea e unificadora. Esse discurso, Bhabha (1998) classifica como performático, pois ele ressignifica enunciados sacralizados e surge a partir de vozes silenciadas que "intervém na soberania da autogeração da nação ao lançar uma sombra entre o povo como "imagem" e sua significação como um signo diferenciador do Eu, distinto do Outro ou do Exterior" (BHABHA, 1998, p. 209, grifo do autor).

Desta forma, a narrativa performática permite que os subalternos alternem as representações dominantes e introduzam a temporalidade do entre-lugar, um local caracterizado como intersticial em que a passagem entre as identidades fixas abre espaço para o hibridismo cultural. Portanto, essa temporalidade pode ser considerada o lócus de enunciação da cultura, em que ocorrem diversas formas de hibridismo e que é construido na articulação das diferenças culturais. Segundo Bhabha (2011, p. 91, grifo do autor):

\footnotetext{
bell hooks é o pseudônimo de Gloria Jean Watkins inspirado em sua avó materna, Bell Blair Hooks. É escrito com letras minúscula por uma opção da escritora.
} 
[...] a estratégia ou o discurso hibrido inaugura um espaço de negociação, onde o poder é desigual, mas a sua articulação pode ser questionável. Tal negociação não é nem assimilação, nem colaboração. Ela possibilita o surgimento de um agenciamento "intersticial", que recusa a representação binária do antagonismo social. Os agenciamentos hibridos encontram a sua voz em uma dialética que não busca a supremacia ou soberania cultural. Eles desdobram a cultura parcial a partir da qual emergem para construir visões de comunidade e versões de memórias históricas, que dão forma narrativa às posições minoritárias que ocupam: o fora do dentro; a parte do todo.

Portanto, a partir das questões analisadas, pode-se afirmar que o romance de Heloisa Maranhão problematiza o passado por meio de contranarrativas, dando voz a personalidades silenciadas pela historiografia oficial. A trajetória de Rosa Maria traz uma reflexão sobre os impactos do sistema escravocrata na sociedade brasileira, atentando para a desqualificação da contribuição africana e para o apagamento dessas identidades na construção do imaginário social. Ademais, ela mostra a história de uma nação hibrida e paradoxal diferente das versões teológicas oficiais, que buscam narrar a construção de uma sociedade homogênea. Rosa Maria transita em espaços significativos, revisando fatos históricos que refletem na construção da sociedade brasileira. No romance, há um resgate da importância do povo africano nesse periodo da história brasileira e também uma exposição dos desafios vividos por esse povo e a forma como os mecanismos opressores ocasionaram a negação dessas identidades. Ademais, através da personagem, fica evidente a forma como o sistema escravocrata não deu espaço para as singularidades culturais e proporcionou a criação de estereótipos e estratégias que contribuem para o silenciamento dos negros.

\section{Considerações finais}

A partir da análise desenvolvida, percebe-se que o romance Rosa Maria Egipcíaca da Vera Cruz complementa a pesquisa feita por Mott (1993), ao abordar questões ligadas à cultura africana e ao sistema escravocrata no Brasil. Como se parodiasse o documento histórico, a escritora proporciona um despertar de vozes que revisa a história da nação refletindo sobre os fatores ligados a uma sociedade construida sob o signo da exploração. Na narrativa ficcional, è possivel identificar semelhanças com o texto produzido pelo historiador como, por exemplo, as personagens principais, padre Xota e Rosa Maria, a viagem para Minas Gerais e a adesão de Rosa ao catolicismo. Além disso, o romance recupera dados históricos do século XVII como é o caso da Invasão Holandesa (1644-1654) e a Inconfidência Mineira (1789). Porém, ao retratar esses fatos, a narrativa apresenta uma fissura, pois seria impossivel Rosa ter vivenciado esses dois momentos em função da impossibilidade de se viver 150 anos.

Essa anacronia não compromete a criticidade da narrativa, pois é a trajetória da personagem que abre espaço para a problematização de questões negadas pela tradição. Nesse sentido, o fator principal seria a temática da escravidão que perpassa toda a narrativa e proporciona a denúncia da exploração feminina, a corrupção da Igreja Católica e a violação cultural dos africanos. Essas acusações surgem através de um discurso indignado e irônico, que é enunciado por alguém que se encontra em uma posição subalterna. Portanto, ao dar a voz a esses sujeitos marginalizados, a escritora valoriza a cultura africana revelando ao leitor a importância desses povos. Por conseguinte, as memórias que não participaram da construção de uma ideia de nação e de uma identidade cultural são reveladas e proporcionam um novo olhar sobre a história a partir de um lócus de enunciação que não se encontra no centro, mas, sim, na margem.

Outro aspecto relevante está relacionado com a construção da narrativa. Conforme retratado na análise do romance, antes de começar a escrever, Heloisa Maranhão aparenta passar por um ritual de candomblé em que ela empresta seu corpo para que Rosa Maria possa contar a sua história. Essa fusão de identidades é pertinente para o contexto em questão, pois quem acaba absorvendo a identidade africana é uma intelectual branca e de prestígio social. Portanto, nesse aspecto, ocorre o inverso do que é apresentado durante a diegese, pois não é Rosa quem absorve a cultura do branco, e sim o branco que absorve a sua cultura. Referente a esse processo de escrita, também é relevante 
ressaltar que a ex-escravizada também era escritora, porém diferentemente de Heloisa Maranhão, não teve sua história legitimada pelos meios culturais.

Nesse sentido, a santa africana precisou de um interlocutor legitimado pela sociedade para contar a sua história e ser ouvida, pois conforme os estudos de Gayatri Spivak (2010) a mulher subalterna até pode conseguir falar, porém não existe um público disposto a escutá-la. Por conseguinte, parecendo ter consciência disso e dialogando com os estudos pós-coloniais, a escritora tenta combater essa subalternidade não falando pelo oprimido, mas criando alternativas para que ele possa ser ouvido. Ao ceder o lugar de fala a Rosa, a escritora busca apresentar uma produção intelectual livre dos interesses ocidentais. Desta forma, ela procura desconstruir o pensamento etnocêntrico, observando a riqueza do universo cultural africano.

Portanto, o romance analisado possibilita uma revisão acerca de várias questões presentes no passado brasileiro que deixaram marcas na sociedade contemporânea. Por meio da paródia e da carnavalização a autora questiona a história constituida no Centro a partir da perspectiva de grupos marginalizados e excluidos. Por conseguinte, observa-se uma subversão do poder instituido, questionando e denunciando os mecanismos opressores que estruturaram a sociedade brasileira e deixaram suas marcas na sociedade contemporânea erguida sob um falso lema de democracia racial.

\section{Referências}

ALMEIDA, Sandra Regina Goulart. Mobilidades culturais, geográficas afetivas: espaço urbano e gênero na literatura contemporânea. In: DALCASTAGNE, Regina; LEAL, Virginia Maria Vasconcelos. Espaços e gênero na literatura contemporânea. Porto Alegre: ZOUK, 2015. p. 15-37. https://doi.org/10.17851/23589787.24.1.203-206

BENJAMIN, Walter. Sobre o conceito de história. In BENJAMIN, Walter. Magia e técnica, arte e política. São Paulo: Brasiliense, 1987. v.1. (Obras escolhidas.)

BHABHA, Homi K. O local da cultura. Belo Horizonte: Editora UFMG, 1998

BHABHA, Homi K. O bazar global e o clube dos cavalheiros ingleses: textos seletos. Rio de Janeiro: Rocco, 2011.
DALCASTAGNĖ, Regina.Vozes na sombra: representação e legitimidade na narrativa contemporânea. In: DALCASTAGNĖ, Regina (org.).Ver e imaginar o outro: alteridade, desigualdade, violência na literatura brasileira contemporânea. São Paulo: Editora Horizonte, 2008a. p. 78-107. https://doi.org/10.17851/2358-9787.24.1.203-206

DALCASTAGNĖ, Regina. Entre silêncios e estereótipos: relações raciais na literatura brasileira contemporânea. Estudos de Literatura Brasileira Contemporânea, Brasília, n. 31, jan./jun. 2008b. Disponivel em: http://periodicos.unb.br/index.php/estudos/article/ view/2021. Acesso em: 20 dez. 2018. https://doi. org/10.1590/s2316-40182012000200002

FANON, Frantz. Pele negra, máscaras brancas. Bahia: Editora Edufba, 2008

GRINBERG, Keila. Castigos físicos e legislação. In: SCHWARCZ, Lilia M.; GOMES, Flávio (org.). Dicionário da escravidão e liberdade: 50 textos críticos. Rio de Janeiro: Companhia das Letras, 2018. p. 144-148. https://doi.org/10.7476/9788523212148

HOOKS, bell. Não sou eu uma mulher: mulheres negras e o feminismo. Trad. Livre Plataforma Gueto, 2014. Disponivel em: https://plataformagueto.files. wordpress.com/2014/12/nc3a3o-sou-eu-uma-mulher_traduzido.pdf. Acesso em: 01 jan. 2019. https:// doi.org/10.11606/t.22.2007.tde-19122007-152429

HUCHEON, Linda. Poética do pós-modernismo. Rio de Janeiro: Imago, 1991.

LOBO, Luisa. Literatura e história: uma intertextualidade importante. In: DUARTE, Constância lima; DUARTE, Eduardo de Assis; BEZERRA, Kátia. da Costa. Gênero e representação: teoria, história e crítica. Belo Horizonte: UFMG, 2002. p. 108-117. V. 1. (Coleção Mulher e Literatura.)

MARANHÃO, Heloísa. Rosa Maria Egipciaca da Vera Cruz: a incrivel trajetória de uma princesa negra entre a prostituição e a santidade. Rio de Janeiro: Rosa dos tempos, 1997.

MACHADO, Maria Helena Pereira Toledo. Mulher, corpo e maternidade. In: SCHWARCZ, Lilia M.; GOMES, Flávio (org.). Dicionário da escravidão e liberdade: 50 textos críticos. Rio de Janeiro: Companhia das Letras, 2018. p. 334-340.

MOTT, Luiz. Rosa Egipciaca: uma Santa Africana no Brasil. Rio de Janeiro: Bertrand Brasil, 1993.

NASCIMENTO, Abdias. O genocídio do negro brasileiro: processo de racismo mascarado. 3. ed. São Paulo Perspectivas, 2016. https://doi.org/10.26694/rcp. issn.2317-3254.v8e1.2019.p9. $93-96$

PINTO, Marcela de Araújo. Lares literários: metáforas de nacionalidade em Paradise (1997), de Toni Morrison, e em Rosa Maria Egipciaca (1997), de Heloisa Maranhão. São Paulo: Cultura Acadêmica, 2014.

SAID, Edward. Cultura e imperialismo. São Paulo: Companhia das Letras, 2011.

SPIVAK, Gayatri. Pode o subalterno falar? Belo Horizonte: Editora UFMG, 2010 


\section{Endereço para correspondência}

Francine Vargas dos Santos Damasceno

Universidade Federal do Rio Grande do Sul

Av. Bento Gonçalves, 9500, Prédio 43221, Sala 122

Agronomia, 91501970

Porto Alegre, RS, Brasil

\section{Francine Vargas dos Santos Damasceno}

Mestranda em Estudos de Literatura pela Universidade Federal do Rio Grande do Sul (UFRGS, Porto Alegre, RS, Brasil). 